Research Article

\title{
Microstructure Changes and Improvement in the Mechanical Properties of As-Cast AlSi7MgCu0.5 Alloy Induced by the Heat Treatment and ECAP Technique at Room Temperature
}

\author{
Miloš Matvija (D, ${ }^{1}$ Martin Fujda, ${ }^{1}$ Ondrej Milkovičc, ${ }^{1,2}$ Marek Vojtko, ${ }^{2}$ Róbert Kočiško, ${ }^{3}$ \\ and Miroslav Glogovský ${ }^{1}$ \\ ${ }^{1}$ Department of Materials Engineering, Institute of Materials and Quality Engineering, \\ Faculty of Materials, Metallurgy and Recycling, Technical University of Košice, Letná 9, 04200 Košice, Slovakia \\ ${ }^{2}$ Institute of Materials Research, Slovak Academy of Science, Watsonova 47, 04001 Košice, Slovakia \\ ${ }^{3}$ Department of Plastic Deformations and Process Simulations, Institute of Materials and Quality Engineering, \\ Faculty of Materials, Metallurgy and Recycling, Technical University of Košice, Letná 9, 04200 Košice, Slovakia \\ Correspondence should be addressed to Miloš Matvija; milos.matvija@tuke.sk
}

Received 29 March 2018; Accepted 7 May 2018; Published 3 June 2018

Academic Editor: Pavel Lejcek

Copyright @ 2018 Miloš Matvija et al. This is an open access article distributed under the Creative Commons Attribution License, which permits unrestricted use, distribution, and reproduction in any medium, provided the original work is properly cited.

\begin{abstract}
The changes in the microstructure and improvement in the mechanical properties of as-cast AlSi7MgCu0.5 alloy induced by the heat treatment and technique of equal channel angular pressing (ECAP) were investigated. The heat treatment of as-cast alloy performed before the ECAP technique was required to increase the plasticity of the alloy. Therefore, the samples of analysed alloys were solution annealed at optimized temperature of $823 \mathrm{~K}$ for 4 hours to dissolve the particles of intermetallic $\pi\left(\mathrm{Al}_{8} \mathrm{FeMg}_{3} \mathrm{Si}_{6}\right)$ phase and to spheroidize the Si particles. Subsequently, water quenching and artificial ageing at optimized temperature of $573 \mathrm{~K}$ for 5 hours was used to obtain an overaged alloy state. The microstructure of alloy was consisted of $\alpha(\mathrm{Al})$ solid solution, eutectic $\mathrm{Si}$ particles, and intermetallic $\beta\left(\mathrm{Mg}_{2} \mathrm{Si}\right), \mathrm{Q}-\mathrm{Al}_{4} \mathrm{Mg}_{5} \mathrm{Si}_{4} \mathrm{Cu}, \alpha-\mathrm{Al}_{12}(\mathrm{Fe}, \mathrm{Mn})_{3} \mathrm{Si}$, and/or $\alpha-\mathrm{Al}_{15}(\mathrm{Fe}, \mathrm{Mn})_{3} \mathrm{Si}_{2}$ phase particles. The crystal structure of present phases was confirmed by hard X-ray diffraction at Deutsches Elektronen-Synchrotron (DESY) in Hamburg and by the selected area electron diffraction (SAED) performed inside the transmission electron microscope (TEM). The heattreated alloy was processed by ECAP at room temperature following route A. Repetitive ECAP of alloy homogenized the heterogeneous as-cast microstructure and formed the ultrafine subgrain microstructure with elongated subgrains of $0.2 \mu \mathrm{m}$ in width and $0.65 \mu \mathrm{m}$ in length and the high dislocation density. Microstructural changes in alloy induced by both heat treatment and ECAP led to the high strain hardening of the alloy that appeared in an improvement in strength, ductility, and microhardness of alloy in comparison with as-cast alloy state.
\end{abstract}

\section{Introduction}

Hypoeutectic aluminium-silicon alloys are well-known casting materials used in automotive industry due to their excellent castability, high strength-to-weight ratio, good mechanical properties at elevated temperature, good wear resistance, and low thermal-expansion coefficient [1]. However, the low toughness and ductility of these alloys limit their wider applications, especially for engineering applications. These limitations are as a result of heterogeneous structure of alloys that consists of $\alpha$-solid solution, eutectic Si particles, and Fe- and Mn-rich intermetallic phase particles with undesirable morphology, size, and distribution that are regarded as impurities [2].

The addition of $\mathrm{Mg}$ and $\mathrm{Cu}$ to $\mathrm{Al}-\mathrm{Si}$ alloys and the optimized heat treatment can improve the mechanical properties of these alloys. Those added elements allow their solid-solution hardening and precipitation hardening. The heat treatment including solution annealing, quenching, and ageing is the most widely used method to improve strength properties of these alloys due to the formation of precipitates from supersaturated solid solution during applied natural or 
TABle 1: Chemical composition of AlSi7MgCu0.5 alloy.

\begin{tabular}{lccccccccr}
\hline Element & $\mathrm{Si}$ & $\mathrm{Mg}$ & $\mathrm{Cu}$ & $\mathrm{Fe}$ & $\mathrm{Mn}$ & $\mathrm{Zn}$ & $\mathrm{Sr}$ & $\mathrm{Ti}$ & $\mathrm{Al}$ \\
\hline wt.\% & 6.49 & 0.38 & 0.45 & 0.11 & 0.08 & 0.01 & 0.03 & 0.11 & $\mathrm{Bal}$. \\
\hline
\end{tabular}

artificial ageing [3]. During the initial stage of the artificial ageing, the strength and hardness of alloys increases up to the maximum value. It is a result of the formation of coherent and/or semicoherent strengthening phase particles. The decrease in strength of alloys after extended ageing time and/or at high ageing temperature is accompanied by an increase in their plasticity due to the formation of incoherent strengthening phase particles and their coarsening [4].

Besides the heat treatment of $\mathrm{Al}-\mathrm{Si}-\mathrm{Mg}-\mathrm{Cu}$ alloys performed to improve their strength and plasticity, the techniques of severe plastic deformation (SPD) have been often used in the last decades. These techniques utilize deformation mechanism to refinement and homogenization of microstructure and grain-size strengthening and work or strain hardening of these alloys. Among all SPD techniques, the ECAP is widely used in the research of aluminium alloys, especially due to the production of ultrafine grained (UFG) structures of alloys and the billets of appropriate size for various structural applications $[5,6]$. The advantage and uniqueness of this method compared to the other methods of SPD is that pressed billets have the same initial and final size of the cross section. In the corner of ECAP die, the UFG structure of severely deformed alloys is formed by simple shear. Moreover, in the case of alloys with heterogeneous chemical composition and microstructure, the homogenization of material occurs. However, the final results of this technique depend above all on geometry of die, processing route, number of passes, and temperature of processing [7].

The aim of the present work is to investigate the effect of the repetitive ECAP processing at room temperature on the microstructure and mechanical properties of overaged foundry AlSi7MgCu0.5 alloy.

\section{Materials and Methods}

The commercial AlSi7MgCu0.5 alloy casting, with a chemical composition shown in Table 1, was used for the investigation. The optimal character of as-cast structure was achieved by the melt modification with $\mathrm{Sr}$ and inoculation with commercial AlTi-B grain refiner. The samples cut from the casting surface in the depth of $10 \mathrm{~mm}$ were used as an initial as-cast state. The cylindrical billets of the as-cast alloy state with the dimensions of $10 \mathrm{~mm}$ in diameter and $100 \mathrm{~mm}$ long were solution annealed at $823 \mathrm{~K}$ for 4 hours, subsequently water-quenched and artificially aged at $573 \mathrm{~K}$ for 5 hours to obtain overaged alloy state. After this pre-ECAP heat treatment, the experimental billets were severely deformed by the ECAP technique at room temperature by 4 passes through the die with the angle between channels $\Phi=90^{\circ}$ and angle on outer corner of die $\Psi=37^{\circ}$. The billets were processed using route A in ECAP die, where the billets were not rotated between individual passes. The repetitive billet passing by this route is the most effective in refinement and homogenization of as-cast structure of Al-Si alloys [8].

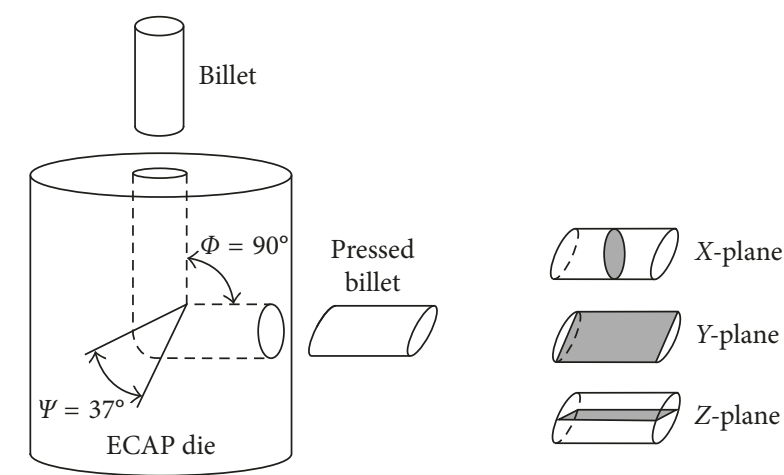

FIGURE 1: Scheme of ECAP technique and designation of the planes of pressed billet.

The microstructure of as-cast, overaged, and ECAPed alloy state was observed by using the light microscope (LM) and scanning electron microscope (SEM). Metallographic samples were prepared by grinding, polishing, etching in the solution of $0.5 \% \mathrm{HF}$ in distilled water, and/or deep etching in the solution of $7 \%$ hydrochloric acid, $13 \%$ nitric acid, and $80 \%$ acetic acid. After ECAP processing, the microstructure and substructure of alloy were studied in the $X$-plane (perpendicular plane to the pressing direction), as shown in Figure 1. The substructure of alloy was observed by the transmission electron microscopy (TEM) on the finally thinned foils in a solution of 33\% nitric acid and 67\% methanol at a temperature of $238 \mathrm{~K}$ and voltage of $16 \mathrm{~V}$. The phase analysis of alloy states was realized by hard X-ray diffraction (XRD) at P02.1 beamline at PETRA III storage ring at Deutsches Elektronen-Synchrotron (DESY) in Hamburg. The tensile test of alloy states was carried out on short cylindrical samples at an initial strain rate of $2.5 \times 10^{-4} \cdot \mathrm{s}^{-1}$ at room temperature. The gauge length of short test samples of $5 \mathrm{~mm}$ diameter was $10 \mathrm{~mm}$. The tensile strength characteristics ( $R_{\mathrm{p} 0.2}$ : yield strength; $R_{\mathrm{m}}$ : tensile strength) and ductility characteristics ( $A$ : tensile elongation; $A_{\mathrm{g}}$ : uniform tensile elongation; $Z$ : reduction of area) were determined. Vickers microhardness measurements were made on the $X$-plane of samples at a load of $200 \mathrm{~g}$ and a loading time of 30 seconds.

\section{Results}

3.1. Microstructure of As-Cast Alloy State. The microstructure of as-cast AlSi7MgCu0.5 alloy state (Figure 2(a)) was dendritic and heterogeneous. It consists of $\alpha(\mathrm{Al})$ solid solution dendrites, interdendritic networks of eutectic silicon particles, and $\alpha$-solid solution and particles of intermetallic phases. Figure 2(b) shows the eutectic and intermetallic phase particles in the microstructure of deep-etched alloy. The morphology of eutectic Si particles was fibrous and coral-like. The particles of intermetallic phases were rod-like and of irregular script morphology. The phase analysis by hard XRD showed that the $\alpha(\mathrm{Al})$ solid solution and eutectic $\mathrm{Si}$ particles were predominant phases in as-cast alloy state (Figure 3(a)). The presence of $\pi\left(\mathrm{Al}_{8} \mathrm{FeMg}_{3} \mathrm{Si}_{6}\right), \beta\left(\mathrm{Mg}_{2} \mathrm{Si}\right)$, Q- $\mathrm{Al}_{4} \mathrm{Mg}_{8} \mathrm{Si}_{7} \mathrm{Cu}_{2}$ and $\alpha-\mathrm{Al}_{12}(\mathrm{Fe}, \mathrm{Mn})_{3} \mathrm{Si}$, and $/$ or $\alpha-\mathrm{Al}_{15}(\mathrm{Fe}$, $\mathrm{Mn})_{3} \mathrm{Si}_{2}$ phases was also detected by diffraction analysis 

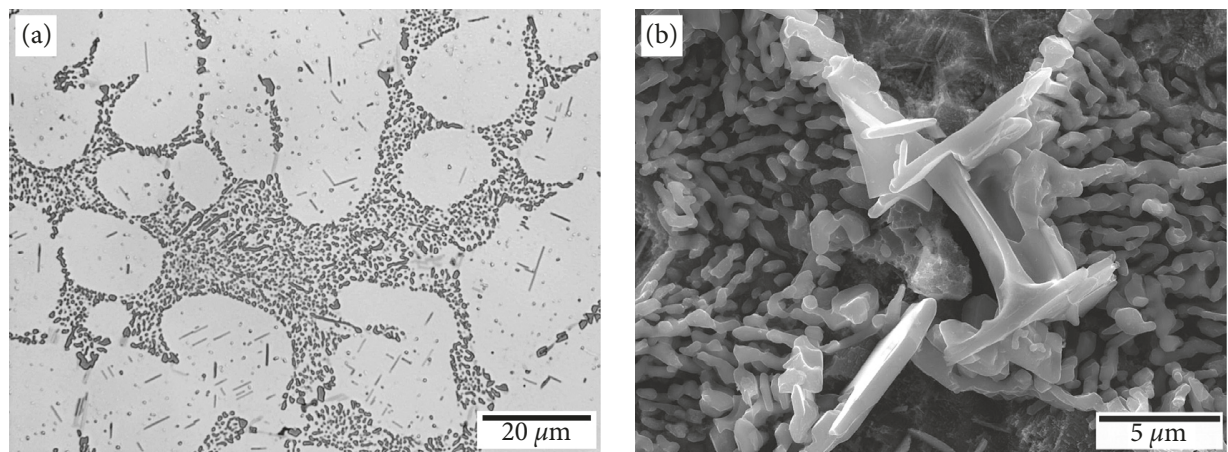

Figure 2: As-cast microstructure of AlSi7MgCu0.5 alloy observed by (a) LM after etching and (b) SEM after deep etching.

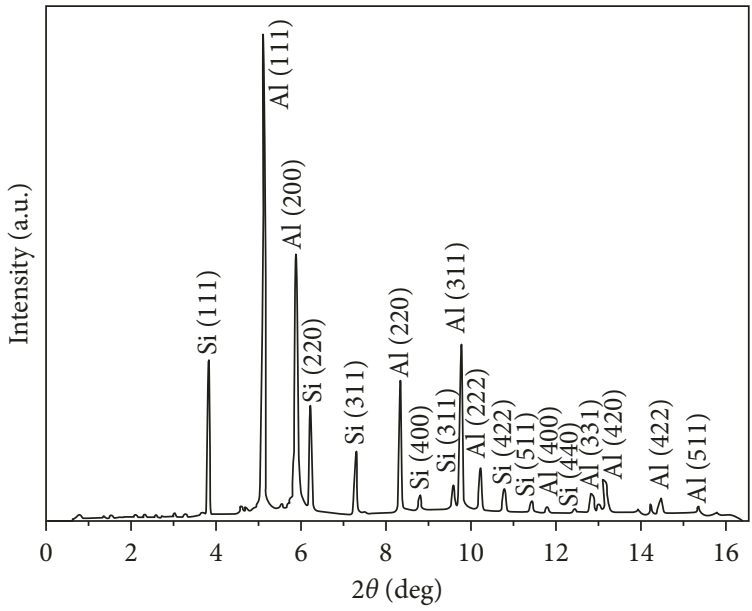

(a)

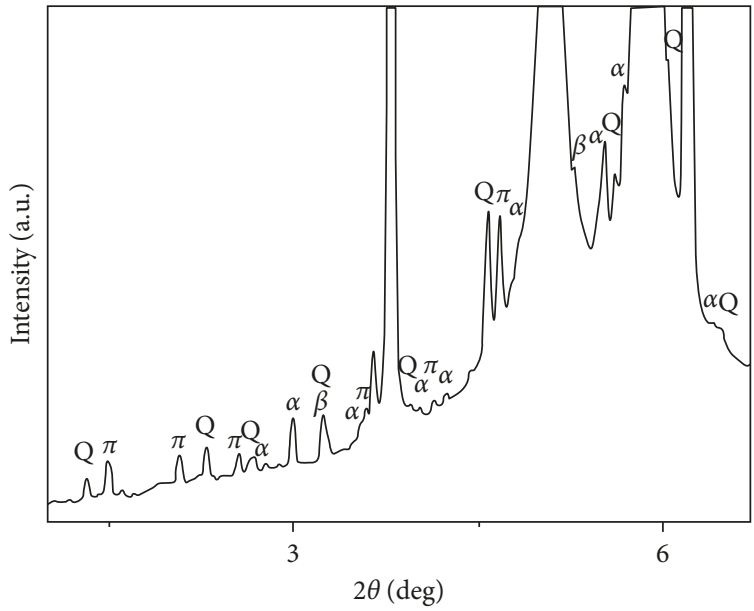

(b)

Figure 3: X-ray diffraction patterns of AlSi7MgCu0.5 alloy in as-cast state: (a) major phases; (b) minor phases.
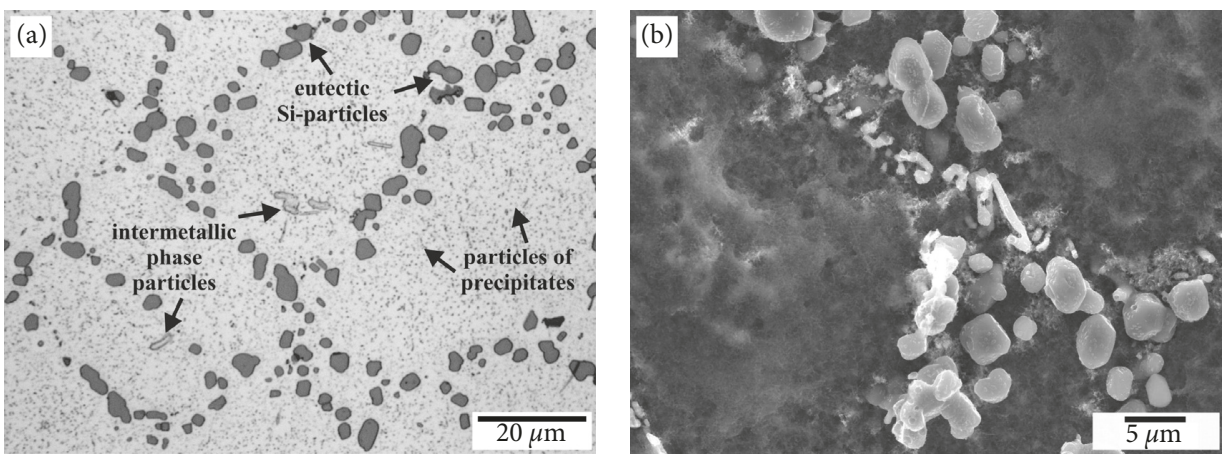

FIgURE 4: Microstructure of AlSi7MgCu0.5 alloy in overaged state observed by (a) LM after etching and (b) SEM after deep etching.

(Figure 3(b)). The positions of $\alpha-\mathrm{Al}_{12}(\mathrm{Fe}, \mathrm{Mn})_{3} \mathrm{Si}$ and $\alpha-\mathrm{Al}_{15}(\mathrm{Fe}, \mathrm{Mn})_{3} \mathrm{Si}_{2}$ maximum intensities responded to the same angle $2 \theta$ in the diffraction patterns in comparison with the measured diffraction data with minor deviations. The presence of phase with both stoichiometries in the as-cast alloy state is possible.
3.2. Microstructure of Overaged Alloy State. The microstructure of the pre-ECAP heat-treated alloy state (after solution annealing, quenching, and artificial ageing) is shown in Figure 4(a). Morphology of particular phases in the microstructure of alloy is visible in Figure 4(b). The application of heat treatment did not change the heterogeneous 


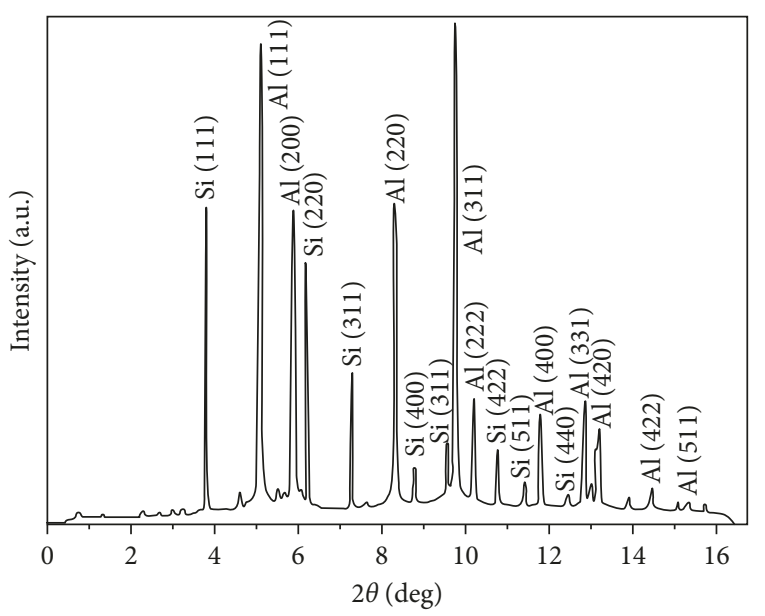

(a)

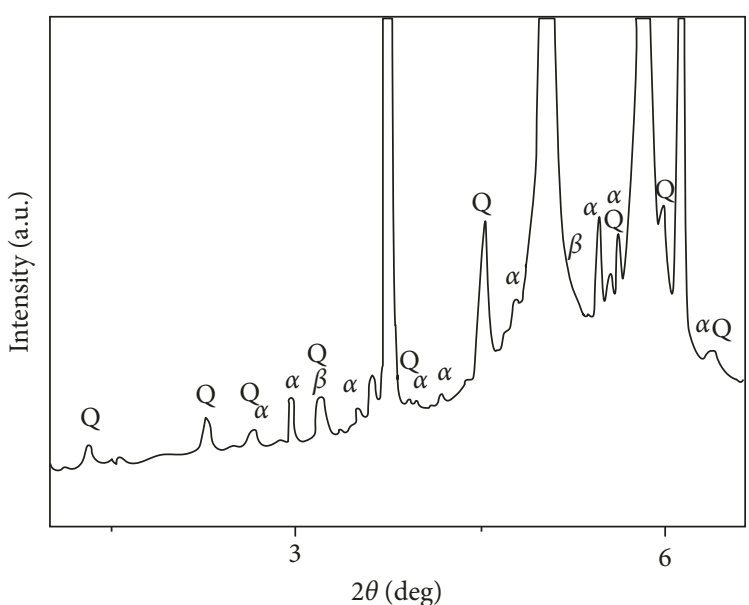

(b)

FIgURE 5: X-ray diffraction patterns of AlSi7MgCu0.5 alloy in overaged state: (a) major phases; (b) minor phases.
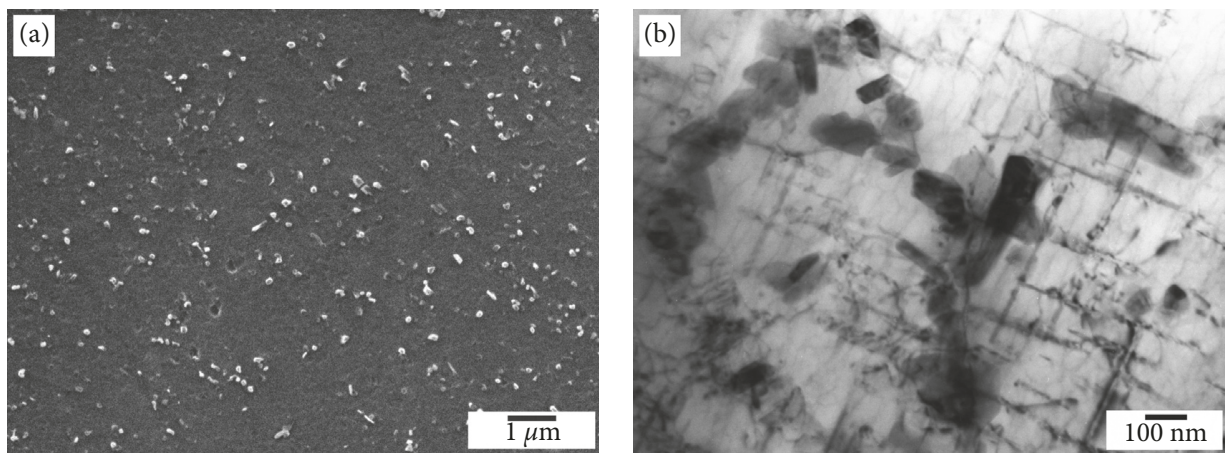

FIgURE 6: Precipitated particles from $\alpha(\mathrm{Al})$ solid solution of AlSi7MgCu0.5 alloy during artificial ageing observed by (a) SEM and (b) TEM.

microstructure of alloy and dendritic character of $\alpha(\mathrm{Al})$ solid solution. However, during solution annealing, the partial spheroidization and coarsening of eutectic Si particles and $\alpha-\mathrm{Al}_{12}(\mathrm{Fe}, \mathrm{Mn})_{3} \mathrm{Si}$ and/or $\alpha-\mathrm{Al}_{15}(\mathrm{Fe}, \mathrm{Mn})_{3} \mathrm{Si}_{2}$ particles occurred. The presence of major phases, $\alpha(\mathrm{Al})$ solid solution and eutectic Si-particles, in overaged alloy state was confirmed by XRD analysis, as shown in Figure 5(a). The comparison of diffraction patterns obtained for this alloy state (Figure 5(b)) with patterns of the as-cast alloy state (Figure 3(b)) showed that the intermetallic $\pi\left(\mathrm{Al}_{8} \mathrm{FeMg}_{3} \mathrm{Si}_{6}\right)$ phase particles were dissolved during solution treatment. On the contrary, the intensity of $\alpha-\mathrm{Al}_{12}(\mathrm{Fe}, \mathrm{Mn})_{3} \mathrm{Si}$ and/or $\alpha-\mathrm{Al}_{15}(\mathrm{Fe}, \mathrm{Mn})_{3} \mathrm{Si}_{2}$ phase was slightly increased. And finally, the intensity of intermetallic $\mathrm{Q}-\mathrm{Al}_{4} \mathrm{Mg}_{8} \mathrm{Si}_{7} \mathrm{Cu}_{2}$ phase increased significantly, and the intensity of $\beta\left(\mathrm{Mg}_{2} \mathrm{Si}\right)$ phase increased slightly. The presence of these intermetallic particles in the microstructure of overaged alloy state was also confirmed by the SAED. It was also found that during artificial ageing the precipitation of incoherent particles of $\beta\left(\mathrm{Mg}_{2} \mathrm{Si}\right)$ phase, $\mathrm{Q}-\mathrm{Al}_{4} \mathrm{Mg}_{5} \mathrm{Si}_{4} \mathrm{Cu}$ phase, $\mathrm{Al}_{x} \mathrm{Fe}_{y} \mathrm{Si}_{z}$ phase, and Si-particles from $\alpha(\mathrm{Al})$ solid solution occurred (Figure 6(b)). Particles of precipitated phases were distributed in the alloy solid solution homogeneously, as shown in Figure 6(a).
3.3. Microstructure of Alloy after ECAP Processing. ECAP processing led to the significant microstructure change of heattreated AlSi7MgCu0.5 alloy state. The microstructure of this state after 4 passes of billet through equal channel at room temperature in $X, Y$, and $Z$ planes are shown in Figures 7(a), $7(\mathrm{c})$, and $7(\mathrm{e})$.

The comparison of overaged (Figure 4(a)) and ECAPed (Figure 7(a)) alloy microstructure shows that the dendritic structure of the alloy was effectively homogenized through the fragmentation and redistribution of eutectic Si particles, intermetallic phases particles, and precipitates. After ECAP technique, the change of eutectic Si-particles morphology did not occur; however, their uneven arrangement in solid solution was changed to a line in the $X$ and $Y$ planes of pressed billet. In the $Z$-plane the homogenization of $\mathrm{Si}$ particles, distribution in the matrix was negligible, due to deformation character of pressed billets by route A.

The fragmentation of particles present in the alloy structure was confirmed by evaluation of their average size $(d)$ and number per unit area $(n)$ in the $X$-plane of pressed billet, as shown in Table 2. ECAP led to the decrease of average size and the increase of number per unit area of $\mathrm{Si}$ particles, intermetallic phase particles, and precipitates in 

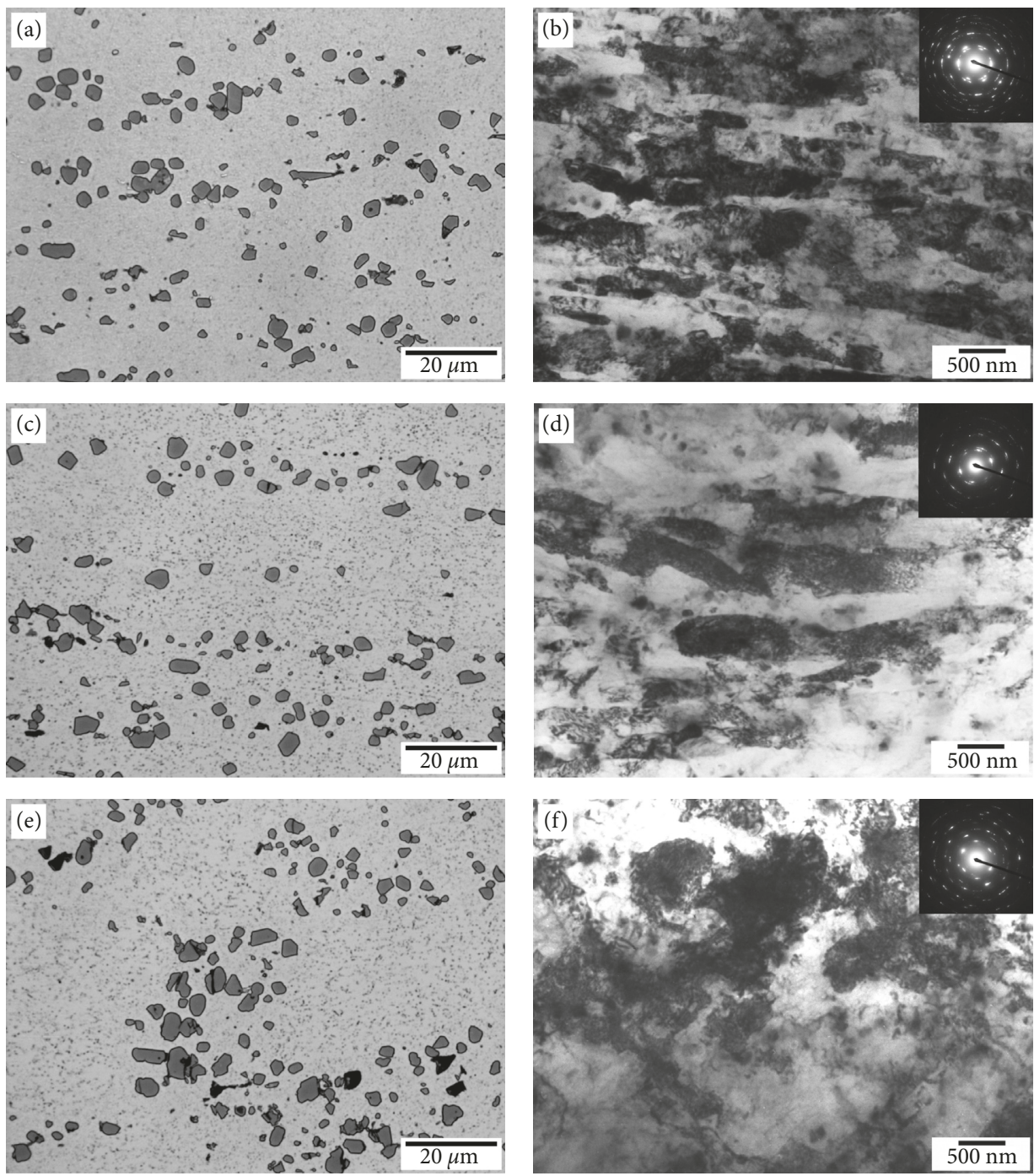

FIgURE 7: Microstructures and substructures with SAED of AlSi7MgCu0.5 alloy after ECAP observed by (a) LM in $X$-plane, (b) TEM in X-plane, (c) LM in Y-plane, (d) TEM in Y-plane, (e) LM in Z-plane, and (f) TEM in Z-plane.

Table 2: Average size $(d)$ and number per unit area $(n)$ of the particles present in microstructure of AlSi7MgCu0.5 alloy [9].

\begin{tabular}{lcccccc}
\hline Alloy state & $\begin{array}{c}\text { Eutectic silicon } \\
\text { particles }\end{array}$ & $\begin{array}{c}\text { Particles of } \\
\text { intermetallic } \\
\text { phases }\end{array}$ & $\begin{array}{c}\text { Particles of } \\
\text { precipitates }\end{array}$ \\
& $\begin{array}{c}d \\
(\mu \mathrm{m})\end{array}$ & $\begin{array}{c}n \\
\left(\mathrm{~mm}^{-2}\right)\end{array}$ & $\begin{array}{c}n \\
(\mu \mathrm{m})\end{array}$ & $\begin{array}{c}n \\
\left(\mathrm{~mm}^{-2}\right)\end{array}$ & $\begin{array}{c}d \\
(\mathrm{~nm})\end{array}$ & $\begin{array}{c}n \\
\left(\mathrm{~mm}^{-2}\right)\end{array}$ \\
\hline As-cast & 0.5 & $21.3 \times 10^{4}$ & 1.9 & $0.31 \times 10^{4}$ & - & - \\
Overaged & 3.0 & $1.0 \times 10^{4}$ & 2.0 & $0.09 \times 10^{4}$ & 114 & $3.5 \times 10^{6}$ \\
ECAPed & 2.5 & $1.5 \times 10^{4}$ & 1.6 & $0.18 \times 10^{4}$ & 77 & $8.1 \times 10^{6}$ \\
\hline
\end{tabular}

microstructure of alloy in comparison with un-deformed overaged alloy state.

Phase identification of ECAPed AlSi7MgCu0.5 alloy by $\mathrm{XRD}$ showed the presence of major and minor phases in its structure. It results from the X-ray diffraction patterns of alloy in Figures 8(a) and 8(b). Al-solid solution and Si-particles were major phases in the analysed alloy state, and $\mathrm{Q}-\mathrm{Al}_{4} \mathrm{Mg}_{8} \mathrm{Si}_{7} \mathrm{Cu}_{2}$, $\beta\left(\mathrm{Mg}_{2} \mathrm{Si}\right), \alpha-\mathrm{Al}_{12}(\mathrm{Fe}, \mathrm{Mn})_{3} \mathrm{Si}$, and/or $\alpha-\mathrm{Al}_{15}(\mathrm{Fe}, \mathrm{Mn})_{3} \mathrm{Si}_{2}$ were minor phases, as well as in the overaged alloy state (Figure 5). Figure 9 shows the dependence between intensity of (111) reflection of $\alpha(\mathrm{Al})$ solid solution of ECAPed alloy and azimuthal angle of the Debye-Scherrer ring. It is possible to observe a strong preferred orientation of solid solution grains.

The ECAP processing of AlSi7MgCu0.5 alloy led to the formation of ultrafine grains of the solid solution. Substructure of 4 times pressed alloy consisted of elongated grains and/or subgrains with nonequilibrium, wavy and curved boundaries, and a high density of dislocations, both within the subgrains and in the zone of the subgrain boundaries, as illustrated in Figures $7(\mathrm{~b})$ and $7(\mathrm{~d})$. The average width of the grains and/or subgrains in the $X$-plane of pressed billet solid solution was $0.2 \mu \mathrm{m}$, and the length was $0.65 \mu \mathrm{m}$. The SAED (Figures 7(b), $7(\mathrm{~d})$, and $7(\mathrm{f}))$ indicated that elongated grains and/or subgrains with preferred orientation (texture) separated by a low angle grain boundaries (LAGBs) and/or high angle grain boundaries (HAGBs) were present in the alloy substructure. The cellular dislocation substructure of deformed AlSi7MgCu0.5 in the Zplane of pressed billet is clear from Figure 7(f). Figure 10 shows 


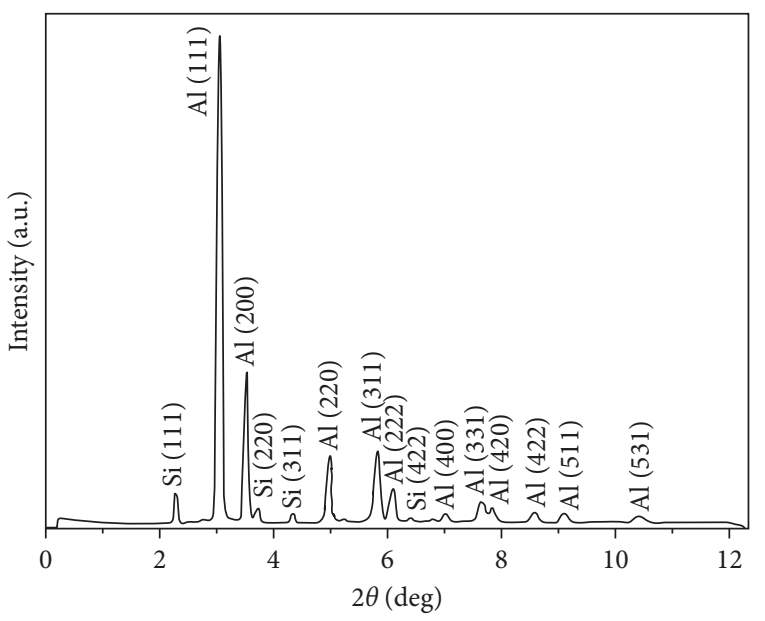

(a)

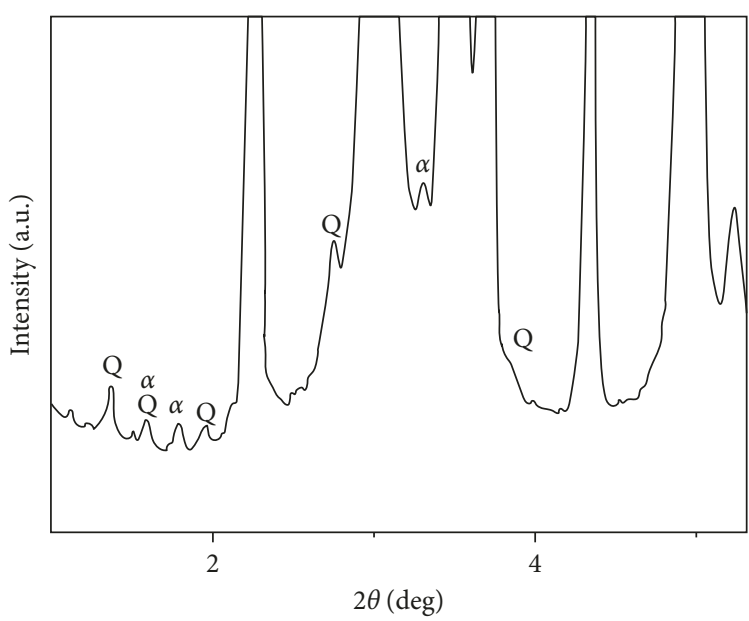

(b)

FIGURE 8: X-ray diffraction patterns of AlSi7MgCu0.5 alloy after ECAP: (a) major phases; (b) minor phases.

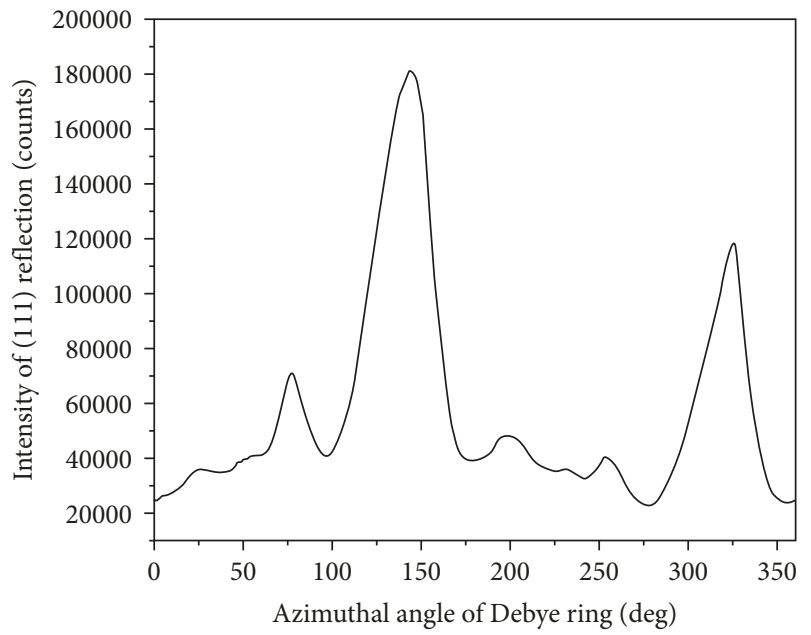

FIGURE 9: Dependence between intensity of (111) reflection of $\alpha(\mathrm{Al})$ solid solution of ECAPed alloy and azimuthal angle of the Debye-Scherrer ring.

the character of grain and/or subgrain boundaries of solid solution.

The grains and/or subgrains of solid solution, with HAGBs and LAGBs observed in ECAPed alloy state, are shown in Figure 11. The size and distribution of these grains and/or subgrains were uneven due to the presence of eutectic Si particles in the structure of alloy. It is clear that elongated subgrains with LAGBs were present in the substructure of alloy in the areas distant from eutectic Si particles. On the contrary, finer equiaxed grains with HAGBs were found close to the Si particles. The presence of these equiaxed grains, with average size of $0.6 \mu \mathrm{m}$ in the deformed structure of alloy, was a result of higher intensity of plastic deformation in areas close to eutectic Si particles. These particles supported the formation of deformed areas. EBSD map shows that these areas were associated with the formation of HAGBs.

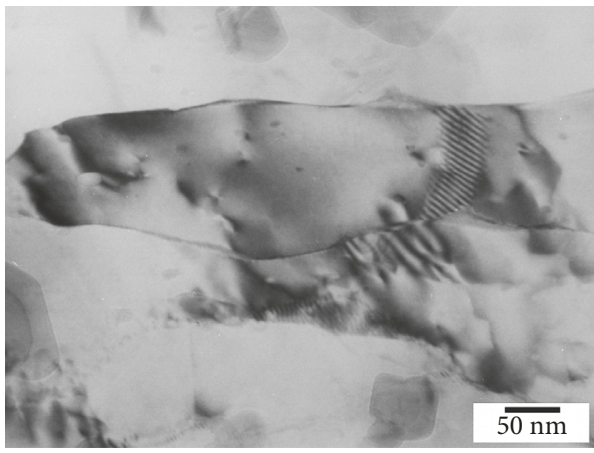

FIgURE 10: Character of AlSi7MgCu0.5 alloy substructure after ECAP in $X$-plane of billet.

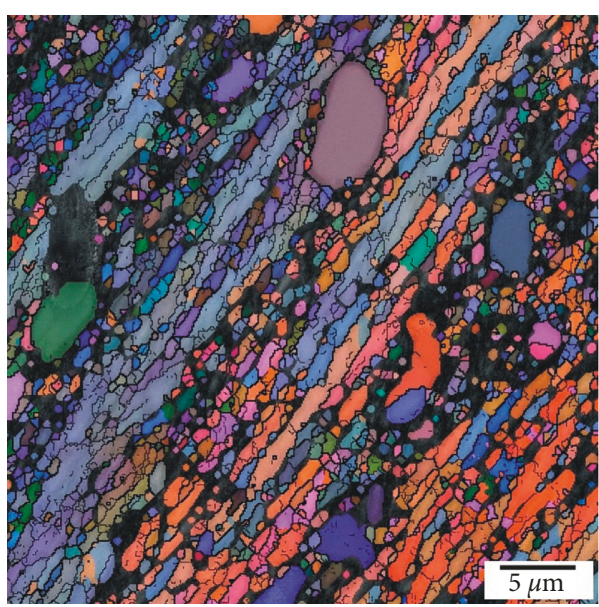

Figure 11: EBSD map of AlSi7MgCu0.5 alloy after ECAP.

3.4. Mechanical Properties of Alloy. The tensile test at room temperature determined the strength and ductile characteristics for as-cast, overaged, and ECAPed AlSi7MgCu0.5 alloy state. The values of mechanical properties obtained by the tensile test are given in Table 3 and obtained stress-strain (R-e) curves for states of analysed alloy are shown in Figure 12. 
TABle 3: The mechanical properties of AlSi7MgCu0.5 alloy.

\begin{tabular}{lcccccc}
\hline $\begin{array}{l}\text { Alloy } \\
\text { state }\end{array}$ & $\begin{array}{c}R_{\mathrm{p} 0.2} \\
(\mathrm{MPa})\end{array}$ & $\begin{array}{c}R_{\mathrm{m}} \\
(\mathrm{MPa})\end{array}$ & $\begin{array}{c}A \\
(\%)\end{array}$ & $\begin{array}{c}A_{\mathrm{g}} \\
(\%)\end{array}$ & $\begin{array}{c}Z \\
(\%)\end{array}$ & HV0.2 \\
\hline As-cast & 127 & 219 & 10.1 & 8.9 & 14.6 & 72.2 \\
Overaged & 136 & 208 & 17.1 & 7.6 & 28.2 & 69.9 \\
ECAPed & 319 & 332 & 14.5 & 1.8 & 21.5 & 110.7 \\
\hline
\end{tabular}

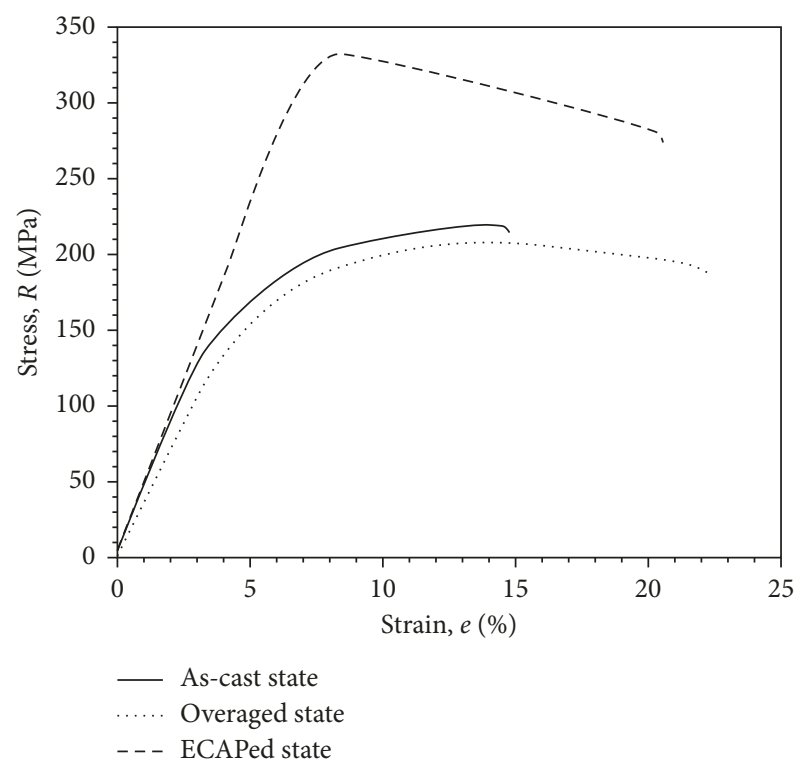

Figure 12: The stress-strain (R-e) curves of AlSi7MgCu0.5 alloy in as-cast, overaged, and ECAPed state as a result of the tensile test at room temperature.

The low characteristics of strength (yield strength and ultimate tensile strength) and ductility (elongation and reduction in area) resulted from the tensile test of as-cast alloy state. The effect of ECAP technique on mechanical properties of the heattreated alloy is clear from the curves. In comparison with ascast alloy state, the yield strength $\left(R_{\mathrm{p} 0.2}\right)$ value of overaged alloy state slightly increased from 127 to $136 \mathrm{MPa}$, and tensile strength $\left(R_{\mathrm{m}}\right)$ of alloy decreased from 219 to $208 \mathrm{MPa}$. PreECAP heat treatment to overaged alloy state also led to the increase of ductile characteristics in comparison with as-cast alloy state. The value of tensile elongation $(A)$ increased from $10.1 \%$ in the as-cast alloy state to $17.1 \%$ in overaged alloy state and the value of reduction of area $(Z)$ increased nearly twice from 14.6 to $28.2 \%$. The increase in the yield strength value at $135 \%$ and tensile strength value at $60 \%$ of analysed alloy was achieved in comparison with overaged alloy state by ECAP processing at room temperature. The slight decrease occurred in tensile elongation (to 14.5\%) and reduction of area (to 21.5\%). However, significant decrease of uniform tensile elongation $\left(A_{\mathrm{g}}\right)$ occurred from 7.6 to $1.8 \%$.

The AlSi7MgCu0.5 alloy in the as-cast state indicated microhardness HV0.2 of 72.2. The heat treatment of analysed alloy to overaged state led to the slight decrease in microhardness to 69.9 and after 4 ECAP passes, the alloy showed value of 110.7 that was of $53 \%$ higher value than ascast alloy state.

\section{Discussion}

The as-cast alloy state with heterogeneous dendritic structure was an initial state for the evaluation of the effect of the ECAP technique on the structure and mechanical properties of AlSi7MgCu0.5 alloy. The as-cast structure consisted of the solid solution dendrites, eutectic Si-particles, and the particles of intermetallic phases that are typical for silumines of this chemical composition [3]. The analyses of phases in the alloy as-cast structure, realized by hard X-ray diffraction, confirmed the presence of major phases $\mathrm{Al}$ ( $\alpha$-solid solution) and $\mathrm{Si}$ (eutectic particles) and minor phases intermetallic Q- $\mathrm{Al}_{4} \mathrm{Mg}_{8} \mathrm{Si}_{7} \mathrm{Cu}_{2}, \pi\left(\mathrm{Al}_{8} \mathrm{FeMg}_{3} \mathrm{Si}_{6}\right), \beta\left(\mathrm{Mg}_{2} \mathrm{Si}\right)$, and $\alpha-\mathrm{Al}_{12}(\mathrm{Fe}$, $\mathrm{Mn})_{3} \mathrm{Si}$ and/or $\alpha-\mathrm{Al}_{15}(\mathrm{Fe}, \mathrm{Mn})_{3} \mathrm{Si}_{2}$ phases. The position of the maximum intensities of $\alpha-\mathrm{Al}_{12}(\mathrm{Fe}, \mathrm{Mn})_{3} \mathrm{Si}$ and $\alpha-\mathrm{Al}_{15}(\mathrm{Fe}$, $\mathrm{Mn})_{3} \mathrm{Si}_{2}$ phases corresponded to the same diffraction angle $2 \theta$ in the diffraction patterns compared to the measured diffraction data with the slight deviations. These small deviations were induced by the change in the lattice parameter through the substitution of Fe and $\mathrm{Mn}$ atoms in the lattice of above mentioned phases [10]. The $\mathrm{Q}-\mathrm{Al}_{4} \mathrm{Mg}_{8} \mathrm{Si}_{7} \mathrm{Cu}_{2}$ phase corresponded to the $\mathrm{Q}-\mathrm{Al}_{4} \mathrm{Mg}_{5} \mathrm{Si}_{4} \mathrm{Cu}$ and also to the $\mathrm{Q}-\mathrm{Al}_{5} \mathrm{Mg}_{8} \mathrm{Si}_{6} \mathrm{Cu}_{2}$ phase that often occur in the microstructure of this type of alloys [11-13], but the $\mathrm{Q}-\mathrm{Al}_{4} \mathrm{Mg}_{8} \mathrm{Si}_{7} \mathrm{Cu}_{2}$ phase was clearly confirmed in the structure of analysed alloy. The average size of eutectic Si particles in the as-cast alloy state was relatively low $(d=0.5 \mu \mathrm{m})$, and the value of their number per unit area was high $\left(n=21.3 \times 10^{4} \mathrm{~mm}^{-2}\right)$. The eutectic Si particles in this alloy state were fibrous and had coral-like morphology common for hypoeutectic modified silumines $[14,15]$. The intermetallic $\mathrm{Q}-\mathrm{Al}_{4} \mathrm{Mg}_{8} \mathrm{Si}_{7} \mathrm{Cu}_{2}$ phase particles of plate-like morphology, $\pi\left(\mathrm{Al}_{8} \mathrm{FeMg}_{3} \mathrm{Si}_{6}\right)$ and $\beta\left(\mathrm{Mg}_{2} \mathrm{Si}\right)$ phases of script-like morphology, and $\alpha-\mathrm{Al}_{12}(\mathrm{Fe}, \mathrm{Mn})_{3} \mathrm{Si}$ and/or $\alpha-\mathrm{Al}_{15}(\mathrm{Fe}, \mathrm{Mn})_{3} \mathrm{Si}_{2}$ rod-like morphology present in microstructure of alloy were also observed in the works of many authors $[13,16]$. The average size of intermetallic particles was $1.9 \mu \mathrm{m}$, and their number per unit area was $0.31 \times 10^{4} \mathrm{~mm}^{-2}$. The particles of intermetallic phases enriched with Fe and/or $\mathrm{Mn}$ in the structure of Al-Si alloys are considered as impurities, and their increased content in the structure reduces the values of strength characteristics, ductility, and toughness of these alloys $[3,17]$. The effect of the as-cast heterogeneous structure of this type alloy and unfavourable morphology of the particles of intermetallic phases on the level of their strength, ductility, and hardness was also investigated by others $[18,19]$.

Subsequently, the as-cast alloy was heat treated before application of the ECAP technique to increase its plasticity. Increased alloy plasticity enabled pressing the alloy billets by maximum number of their passes through channels of ECAP die and thus maximizing the level of their mechanical properties. The analysed alloy was heat treated to overaged state through the combination of optimized solution annealing at $823 \mathrm{~K}$ for 4 hours, water-quenching, and optimized artificial ageing at $573 \mathrm{~K}$ for 5 hours. The spheroidization and significant coarsening of eutectic Si particles which occurred during solution annealing and moreover dissolution of the intermetallic phase particles and their morphology changes were also observed by many authors 
$[3,13,18]$. Alloy annealing process led to the dissolution and/or fragmentation of rod-like Si particles into smaller segments due to reduction of the surface tension of these particles that subsequently spheroidized and through the effect of annealing temperature coarsened by diffuse growth $[3,19]$. The average size of eutectic Si particles increased six times up to $3.0 \mu \mathrm{m}$ and their number per unit area decreased from 21.3 to $1.0 \times 10^{4} \mathrm{~mm}^{-2}$ during heat treatment of analysed alloy before ECAP. The comparison of X-ray diffraction patterns of overaged and as-cast alloy state showed that the dissolution of intermetallic $\pi\left(\mathrm{Al}_{8} \mathrm{FeMg}_{3} \mathrm{Si}_{6}\right)$ phase particles and slight increase in content of intermetallic $\alpha-\mathrm{Al}_{12}(\mathrm{Fe}$, $\mathrm{Mn})_{3} \mathrm{Si}$ or $\alpha-\mathrm{Al}_{15}(\mathrm{Fe}, \mathrm{Mn})_{3} \mathrm{Si}_{2}$ phase particles occurred during solution annealing and artificial ageing of alloy. There was no change in the average size of intermetallic phase particles $(2.0 \mu \mathrm{m})$ in comparison with as-cast alloy state, yet the value of number per unit area significantly decreased by about $70 \%$ to $0.09 \times 10^{4} \mathrm{~mm}^{-2}$. The significant increase in content of Q- $\mathrm{Al}_{4} \mathrm{Mg}_{8} \mathrm{Si}_{7} \mathrm{Cu}_{2}$ phase and slight increase of $\beta\left(\mathrm{Mg}_{2} \mathrm{Si}\right)$ phase in comparison with as-cast alloy state was observed from $\mathrm{X}$-ray diffraction patterns. The presence of these phases in the overaged alloy structure was also confirmed in the work of Farkoosh et al. [13]. However, it is possible to assume that both these phases were dissolved during the solution annealing of alloy and then during artificial ageing, they precipitated from solid solution as incoherent particles $[13,20]$. The selected area electron diffraction confirmed that the precipitation of incoherent particles of $\beta\left(\mathrm{Mg}_{2} \mathrm{Si}\right)$, Q- $\mathrm{Al}_{4} \mathrm{Mg}_{5} \mathrm{Si}_{4} \mathrm{Cu}, \mathrm{Al}_{x} \mathrm{Fe}_{y} \mathrm{Si}_{z}$, and $\mathrm{Si}$ from solid solution occurred during the artificial ageing of analysed alloy. Their average size was $114 \mathrm{~nm}$, and number per unit area was $3.5 \times 10^{6} \mathrm{~mm}^{-2}$. These particles were evenly distributed in solid solution of the analysed alloy. The d-spacing values of Q- $\mathrm{Al}_{4} \mathrm{Mg}_{5} \mathrm{Si}_{4} \mathrm{Cu}$ phase confirmed by SAED and of $\mathrm{Q}-\mathrm{Al}_{4} \mathrm{Mg}_{8} \mathrm{Si}_{7} \mathrm{Cu}_{2}$ phase confirmed by X-ray diffraction were coincided with tolerance of $0.001 \mathrm{~nm}$, but more precise analysis confirmed the presence of $\mathrm{Q}-\mathrm{Al}_{4} \mathrm{Mg}_{5} \mathrm{Si}_{4} \mathrm{Cu}$. The phase of $\mathrm{Al}_{x} \mathrm{Fe}_{y} \mathrm{Si}_{z}$ analysed by SAED can be regarded as the intermetallic phase of $\mathrm{Al}_{12}(\mathrm{Fe}, \mathrm{Mn})_{3} \mathrm{Si}$ and/or $\alpha-\mathrm{Al}_{15}(\mathrm{Fe}, \mathrm{Mn})_{3} \mathrm{Si}_{2}$, and the presence of which was confirmed by X-ray diffraction.

The significant increase in the plasticity of alloy occurred after application of heat treatment which was also investigated in the work of Moradi et al. [18]. The tensile elongation of alloy in the overaged state was increased 1.7 times (to 17.1\%) in comparison with the as-cast alloy state, and furthermore, the strength of alloy did not decrease. The increase of ductility occurred due to the removal of unfavourable morphology of particles in the alloy structure by spheroidization of eutectic Si particles and dissolution of intermetallic phase particles. The uniform precipitation of fine incoherent particles from alloy solid solution during the artificial ageing compensated the decline of strengthening of alloy caused by coarsening of eutectic Si particles and provided almost the same level of alloy yield strength and tensile strength (the change in the range of $10 \mathrm{MPa}$ ) in comparison with the as-cast alloy state.

After the application of pre-ECAP heat treatment, the severe plastic deformation of alloy by ECAP at room temperature was carried out. Correctly chosen conditions of severe plastic deformation had a very favourable effect on the mechanical properties of foundry alloys, as mentioned in the work of others $[8,21-23]$. The experiments, which were the subject of this work, confirmed these findings for AlSi $7 \mathrm{MgCu} 0.5$ alloy and additionally demonstrated the importance of the pre-ECAP heat treatment before severe plastic deformation. Severe plastic deformation of analysed alloy by the ECAP technique at room temperature after heat treatment of alloy significantly changed the character of its microstructure. The fragmentation and redistribution of the eutectic Si particles, particles of intermetallic phases, and particles of precipitates to homogeneous form occurred. Moreover, ultrafine grained alloy structure was formed, which led to increase in strength and plasticity of alloy, as it was reported in works $[18,23]$. The redistribution of $\mathrm{Si}$ particles, confirmed by analyses of microstructure of alloy, was result of repetitive severe plastic deformation by simple shear of billet in the corner of ECAP die channels. The heterogeneous dendritic structure was successfully removed in the $X$-plane and $Y$-plane of the pressed billet, yet the significant heterogeneity of arrangement of Si-particles was retained in the $Z$-plane of the billet. This difference in the billet planes was a result of the mechanism of deformation by the chosen route $\mathrm{A}$, as discussed in detail in many works $[8,23]$. The fragmentation of eutectic Si particles induced by a high degree of deformation reflected in a slight decrease in the average size of Si particles evaluated in the $X$-plane (from 3.0 to $2.5 \mu \mathrm{m}$ ) and a slight increase in the number per unit area at a half in comparison with overaged alloy state. The decrease in average size of intermetallic phase particles in the structure of alloy after ECAP (from 2.0 to $1.6 \mu \mathrm{m}$ ) and double increase in their number per unit area, decrease in average size of precipitated particles (from 114 to $77 \mathrm{~nm}$ ), and double increase of their number per unit area in comparison with overaged alloy state were also results of the fragmentation. The fragmentation of the particles present in the structure of Al-Si alloys after their ECAP processing was also reported in many works [18, 21, 23-26]. Analyses of phases in the microstructure of alloy after ECAP by X-ray diffraction confirmed the presence of minor phase of the same chemical composition as in overaged alloy state before ECAP. In the deformed alloy microstructure, the minor $\alpha-\mathrm{Al}_{15}(\mathrm{Fe}, \mathrm{Mn})_{3} \mathrm{Si}_{2}$ and/or $\alpha-\mathrm{Al}_{12}(\mathrm{Fe}, \mathrm{Mn})_{3} \mathrm{Si}, \beta\left(\mathrm{Mg}_{2} \mathrm{Si}\right)$ and $\mathrm{Q}-\mathrm{Al}_{4} \mathrm{Mg}_{8} \mathrm{Si}_{7} \mathrm{Cu}_{2}$ phases were confirmed. In the solid solution of the analysed alloy after ECAP, the strong preferred orientation of the matrix was observed through the dependence between intensity of (111) reflection of $\alpha(\mathrm{Al})$ solid solution of ECAPed alloy and azimuthal angle of the Debye-Scherrer ring. Preferential orientation was also observed in the case of AlSi7 alloy after ECAP in the work of García-Infanta et al. [8]. The application of ECAP led to the formation of ultrafine grained structure of solid solution of alloy. The elongated grains and/or subgrains with high dislocation density were observed by TEM, and grains and/or subgrains were separated mainly by nonequilibrium, wavy, and curved boundaries, as observed in the works of others $[24,26]$. These grains and/or subgrains of alloy solid solution were separated by HAGBs and LAGBs with a significant degree of texture, what was confirmed by SAED. 
The average width of grains and/or subgrains was on level of $0.2 \mu \mathrm{m}$ and length of $0.65 \mu \mathrm{m}$. These values respond to average width and length of grains and/or subgrains $(0.23 \mu \mathrm{m}$ and $0.58 \mu \mathrm{m}$, resp.) of ECAPed AlSi7 alloy evaluated in the work of Gutierrez-Urrutia et al. [24]. Based on EBSD results, it is clear that the size of deformed grains and/or subgrains was different due to the presence of eutectic Si particles in the structure of alloy. The elongated subgrains of solid solution were observed away from eutectic Si particles. The subgrains analysed using TEM and SAED confirmed that they were separated by LAGBs. The equiaxed grains of deformed solid solution with HAGBs were identified by SAED in the areas close to eutectic Si particles, which are also observed in ECAPed silumines in the works of others $[18,22,24,25]$. The average size of the fine equiaxed grains of alloy solid solution after ECAP was $0.6 \mu \mathrm{m}$. Their size corresponds to the average length of elongated subgrains of solid solution in the areas away from Si particles. These grains of solid solution close to $\mathrm{Si}$ particles acquired the equiaxed shape due to the higher degree of the plastic deformation in these areas in comparison with the areas of solid solution away from Si particles. The higher intensity of deformation led to cumulation of dislocation around coarse Si particles and the process of dynamic recovery of structure in these areas $[19,25]$. Thus, the submicroscopic heterogeneity of the distribution of the eutectic Si particles led to a heterogeneous refinement of solid solution, which consists of the formation of deformation areas with elongated grains and/or subgrains and areas with equiaxed grains.

The application of the ECAP technique led to the significant increase in the strength of overaged alloy. The increase in the yield strength of analysed alloy was more significant than the increase in its tensile strength. The yield strength of the alloy increased by about $135 \%$ (to $319 \mathrm{MPa}$ ), and the tensile strength increased by about 60\% (to $332 \mathrm{MPa}$ ). After ECAP, the values of tensile elongation and the area decreased in comparison with overaged alloy state, but were still higher than in the as-cast alloy state. From Figure 12, the change of character of stress-strain curves of alloy after ECAP is clear. This curve shape is typical for aluminium alloys after severe plastic deformation [27]. The alloy processed by ECAP at room temperature was characterized by a low value of the uniform tensile elongation $A_{\mathrm{g}}=1.8 \%$ (compared to the $8.9 \%$ and $7.6 \%$ in as-cast and overaged state of alloy, resp.) and a high value of the ratio $R_{\mathrm{p} 0.2} / R_{\mathrm{m}}=0.96$, what was a result of strain hardening of severely deformed solid solution of alloy at room temperature. The overall increase in the strength and plasticity of alloy after ECAP was a result of strain hardening of solid solution, hardening of grains and/or subgrains boundaries, redistribution, homogenization and fragmentation of eutectic Si-particles, particles of intermetallic phases, and precipitates in solid solution of analysed alloy [22-24, 28].

\section{Conclusions}

Severe plastic deformation by the ECAP technique at room temperature in combination with pre-ECAP heat treatment of foundry heat-treatable AlSi7MgCu0.5 alloy led to a significant improvement of its mechanical properties through the homogenization and refinement of structure. Realized experiments and analyses and their evaluation and discussion with a knowledge from the technical literature led to these conclusions:

(1) The $\alpha(\mathrm{Al})$ solid solution in dendritic form and eutecticum in form of eutectic Si particles and solid solution were the major phases in the as-cast alloy structure, and intermetallic phases of $\mathrm{Q}\left(\mathrm{Al}_{4} \mathrm{Mg}_{8} \mathrm{Si}_{7} \mathrm{Cu}_{2}\right)$, $\pi\left(\mathrm{Al}_{8} \mathrm{FeMg}_{3} \mathrm{Si}_{6}\right), \beta\left(\mathrm{Mg}_{2} \mathrm{Si}\right)$, and $\alpha-\mathrm{Al}_{12}(\mathrm{Fe}, \mathrm{Mn})_{3} \mathrm{Si}$ and/or $\alpha-\mathrm{Al}_{15}(\mathrm{Fe}, \mathrm{Mn})_{3} \mathrm{Si}_{2}$ were minor phases. The heterogeneity of the as-cast structure and unfavourable morphology of brittle intermetallic particles and eutectic Si particles resulted in a low level of mechanical properties of alloy.

(2) The eutectic Si particles were spheroidized and coarsened during solution annealing of alloy; the $\pi\left(\mathrm{Al}_{8} \mathrm{FeMg}_{3} \mathrm{Si}_{6}\right)$ phase was dissolved and $\alpha-\mathrm{Al}_{12}(\mathrm{Fe}$, $\mathrm{Mn})_{3} \mathrm{Si}$ and/or $\alpha-\mathrm{Al}_{15}(\mathrm{Fe}, \mathrm{Mn})_{3} \mathrm{Si}_{2}$ phases were formed. The $\mathrm{Q}-\mathrm{Al}_{4} \mathrm{Mg}_{8} \mathrm{Si}_{7} \mathrm{Cu}_{2}$ phase during solution annealing was dissolved and $\beta\left(\mathrm{Mg}_{2} \mathrm{Si}\right)$ phase, $\mathrm{Si}$, and probably, $\mathrm{Al}_{x}(\mathrm{Fe}, \mathrm{Mn})_{y} \mathrm{Si}_{z}$ silicides were precipitated from solid solution of alloy during artificial ageing.

(3) The application of pre-ECAP heat treatment to overaged alloy state led to the significant increase in plasticity of the alloy without decrease in the alloy strength.

(4) The ECAP at room temperature of analysed alloy led to the homogenization of its microstructure through the fragmentation and the redistribution of eutectic Si particles, intermetallic phases and particles of precipitates, and formed ultrafine grained structure of alloy. The elongated grains and/or subgrains of solid solution (width of $0.2 \mu \mathrm{m}$, length of $0.65 \mu \mathrm{m}$ ) were formed in the areas distant from eutectic $\mathrm{Si}$ particles, and due to a higher degree of plastic deformation in areas close to Si-particles, the formation of equiaxed grains $(0.6 \mu \mathrm{m})$ of solid solution occurred separated mostly by HAGBs.

(5) The ECAP at room temperature led to the significant increase in strength and ductility of alloy in comparison with the as-cast state. The yield strength and tensile strength of alloy increased to $319 \mathrm{MPa}$ and $332 \mathrm{MPa}$, respectively. The tensile elongation and reduction of area increased to $14.5 \%$ and $21.5 \%$, respectively. The alloy microhardness HV0.2 increased to 110.7. The above-mentioned strengthening and improvement of the ductility were achieved due to the positive changes of microstructure after heat treatment and ECAP processing of alloy at room temperature.

\section{Data Availability}

The results of the research are discussed and compared with the results published in the reviewed articles and books listed in References. These articles and books can be considered as data supporting results. Many of these articles are available online on journals website and expert articles databases. 


\section{Disclosure}

Parts of this research were carried out at PETRA III (beamline P02.1) at DESY, a member of the Helmholtz Association (HGF).

\section{Conflicts of Interest}

The authors declare that there are no conflicts of interest regarding the publication of this paper.

\section{Acknowledgments}

This work was realized within the frame of the Operational Program Research and Development: "The centre of competence for industrial research and development in the field of light metals and composites" (project code ITMS: 26220220154).

\section{References}

[1] N. Haghdadi, A. Zarei-Hanzaki, H. R. Abedi et al., "Evolution of microstructure and mechanical properties in a hypoeutectic $\mathrm{Al}-\mathrm{Si}-\mathrm{Mg}$ alloy processed by accumulative back extrusion," Materials Science and Engineering A, vol. 651, pp. 269-279, 2016.

[2] L. Kuchariková, E. Tillová, J. Belan, and M. Uhríćik, "The effect of casting technology on Fe intermetallic phases in $\mathrm{Al}-\mathrm{Si}$ cast alloy," Manufacturing Technology, vol. 15, pp. 567-571, 2015.

[3] E. Sjölander and S. Seifeddine, "The heat treatment of Al-SiCu-Mg casting alloys," Journal of Materials Processing Technology, vol. 210, no. 10, pp. 1249-1259, 2010.

[4] L. Katgerman and D. Eskin, "Hardening, annealing, and aging," in Handbook of Aluminum: Physical Metallurgy and Processes, G. E. Totten and D. C. MacKenzie, Eds., pp. 259304, Taylor and Francis Group, Boca Raton, FL, USA, 2003.

[5] R. Z. Valiev, R. K. Islamgaliev, and I. V. Alexandrov, "Bulk nanostructured materials from severe plastic deformation," Progress in Materials Science, vol. 45, no. 2, pp. 103-189, 2000.

[6] M. Furukawa, Z. Horita, M. Nemoto, and T. G. Langdon, "The use of severe plastic deformation for microstructural control," Materials Science and Engineering A, vol. 324, no. 1-2, pp. 82-89, 2002.

[7] R. Z. Valiev and T. G. Langdon, "Principles of equal-channel angular pressing as a processing tool for grain refinement," Progress in Materials Science, vol. 51, no. 7, pp. 881-981, 2006.

[8] J. M. García-Infanta, S. Swaminathan, A. P. Zhilyaev et al., "Microstructural development during equal channel angular pressing of hypo-eutectic Al-Si casting alloy by different processing routes," Materials Science and Engineering A, vol. 485, no. 1-2, pp. 160-175, 2008.

[9] M. Matvija, M. Fujda, M. Vojtko, and R. Kočiško, "Homogenization of AlSi7MgCu0.5 alloy as-cast structure by ECAP processing," Materials Science Forum, vol. 782, pp. 390-393, 2014.

[10] W. B. Pearson, "Tabulated lattice parameters and data on element metals and metalloids," in Handbook of Lattice Spacings and Structures of Metals 2, pp. 79-92, Pergamon Press, Oxford, UK, 1968.

[11] A. M. Samuel, P. Ouellet, F. H. Samuel, and H. W. Doty, "Microstructural interpretation of thermal analysis of commercial $319 \mathrm{Al}$ alloy with $\mathrm{Mg}$ and $\mathrm{Sr}$ additions," AFS Transactions, vol. 105, pp. 951-962, 1997.
[12] M. Tiryakioglu and J. T. Staley, "Physical metallurgy and the effect of alloying additions in aluminum alloys," in Handbook of Aluminum: Physical Metallurgy and Processes, G. E. Totten and D. C. MacKenzie, Eds., pp. 259-304, Taylor and Francis Group, Boca Raton, FL, USA, 2003.

[13] A. R. Farkoosh, M. Javidani, M. Hoseini, D. Larouche, and M. Pekguleryuz, "Phase formation in as-solidified and heattreated Al-Si-Cu-Mg-Ni alloys: Thermodynamic assessment and experimental investigation for alloy design," Journal of Alloys and Compounds, vol. 551, pp. 596-606, 2013.

[14] S. Nafisi, R. Ghomaschi, and H. Vali, "Eutectic nucleation in hypoeutectic Al-Si alloys," Materials Characterization, vol. 59, no. 10, pp. 1466-1473, 2008.

[15] M. Fujda and Š. Nižník, "Analysis of the primary structure of gas-engine head cylinder casting,"in Proceedings of 8th InternationalFoundrymen Conference,University of Zagreb, Faculty of Metallurgy, Opatija, Croatia, June 2008.

[16] G. Unterreiter, A. Ludwig, and M. Wu, "Numerical microstructure prediction for an aluminium casting and its experimental validation," China Foundry, vol. 8, pp. 331-336, 2011.

[17] L. Hurtalová, E. Tillová, and M. Chalupová, "Possibilities of Fe-rich phases elimination with using heat treatment in secondary Al-Si-Cu cast alloy," Metalurgija, vol. 54, pp. 3942, 2015.

[18] M. Moradi, M. Nili-Ahmadabadi, and B. Heidarian, "Improvement of mechanical properties of $\mathrm{Al}$ (A356) cast alloy processed by ECAP with different heat treatments," International Journal of Material Forming, vol. 2, no. 1, pp. 85-88, 2009.

[19] C. M. Cepeda-Jiménez, J. M. García-Infanta, A. P. Zhilyaev, O. A. Ruano, and F. Carreño, "Influence of the supersaturated silicon solid solution concentration on the effectiveness of severe plastic deformation processing in Al-7wt.\% Si casting alloy," Materials Science and Engineering A, vol. 528, no. 27, pp. 7938-7947, 2011.

[20] G. Wang, Q. Sun, L. Feng, L. Hui, and C. Jing, "Influence of $\mathrm{Cu}$ content on ageing behavior of AlSiMgCu cast alloys," Materials and Design, vol. 28, no. 3, pp. 1001-1005, 2007.

[21] J. Kim, Y. Nishida, H. Arima, and T. Ando, "Microstructure of Al-Si-Mg alloy processed by rotary-die equal channel angular pressing," Materials Letters, vol. 57, no. 11, pp. 1689-1695, 2003.

[22] I. Gutierrez-Urrutia, M. A. Muñoz-Morris, I. Puertas, C. Luis, and D. G. Morris, "Influence of processing temperature and die angle on the grain microstructure produced by severe deformation of an Al-7\% Si alloy," Materials Science and Engineering A, vol. 475, no. 1-2, pp. 268-278, 2008.

[23] J. M. García-Infanta, A. P. Zhilyaev, C. M. Capeda-Jiménez, O. A. Ruano, and F. Careño, "Effect of the deformation path on the ductility of a hypoeutectic Al-Si casting alloy subjected to equal-channel angular pressing by routes $A, B_{A}, B_{C}$ and $C$," Scripta Materialia, vol. 58, no. 2, pp. 138-141, 2008.

[24] I. Gutierrez-Urrutia, M. A. Muñoz-Morris, and D. G. Morris, "Combination of microstructural parameters to strengthening in an ultrafine-grained Al-7\% Si alloy processed by severe deformation," Acta Materialia, vol. 55, no. 4, pp. 1319-1330, 2007.

[25] P. Szczygiel, H. J. Roven, and O. Reiso, “Annealing of Al-Si alloys after equal-channel angular pressing," Materials Science and Engineering A, vol. 493, no. 1-2, pp. 202-206, 2008.

[26] M. Fujda, O. Milkovič, M. Vojtko, T. Kvačkaj, and T. Donič, "Effect of heat treatment and intensive plastic deformation on microstructure and hardness of hypoeutectic silumines," Hutnícke Listy, vol. 62, pp. 14-19, 2009. 
[27] M. Fujda, M. Matvija, T. Kvačkaj et al., "Structure and properties of AlMgSi alloys after ECAP and post-ECAP ageing," Materiali in Tehnologije, vol. 46, no. 5, pp. 465469, 2012.

[28] N. Hansen, "Boundary strengthening over five length scales," Advanced Engineering Materials, vol. 7, no. 9, pp. 815-821, 2005. 


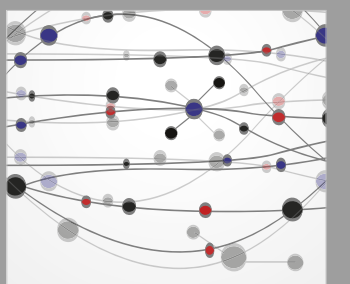

The Scientific World Journal
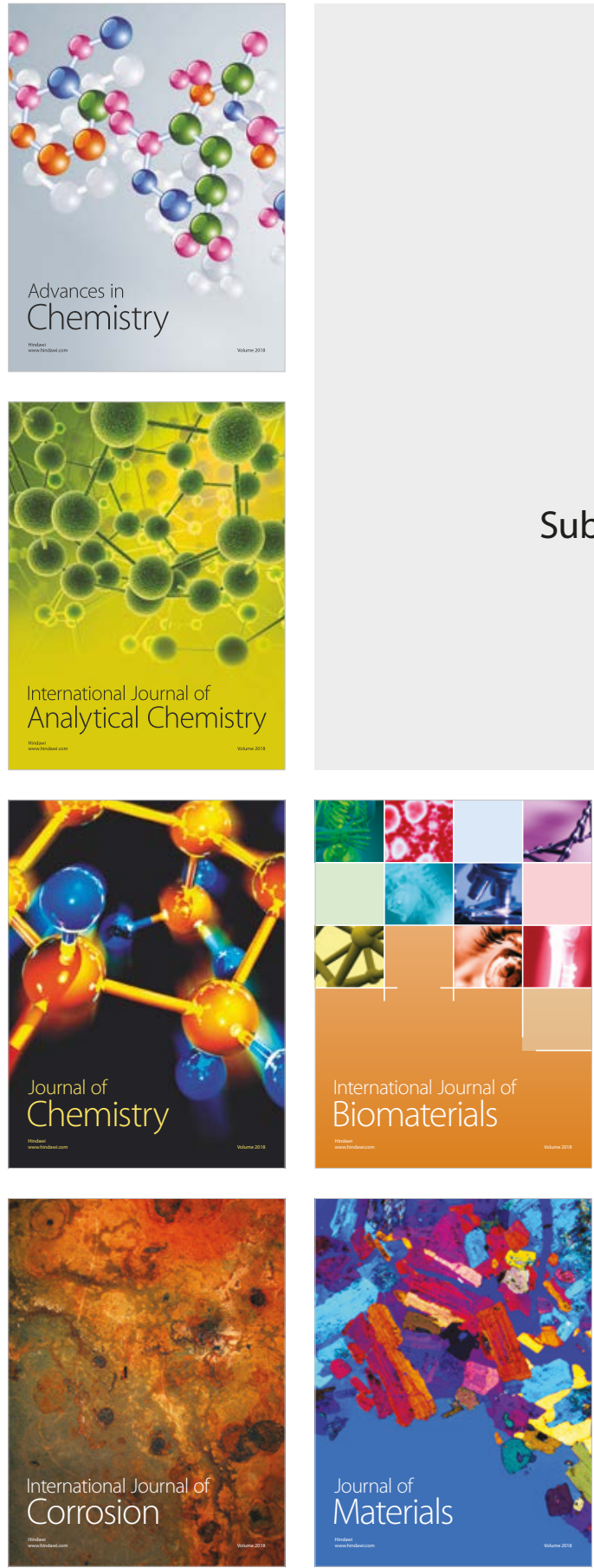

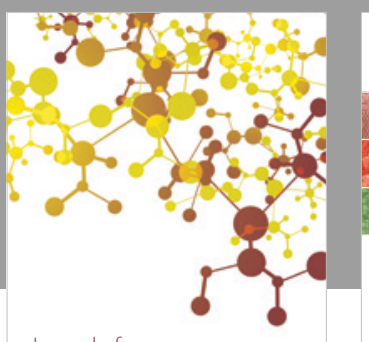

Journal of

Applied Chemistry
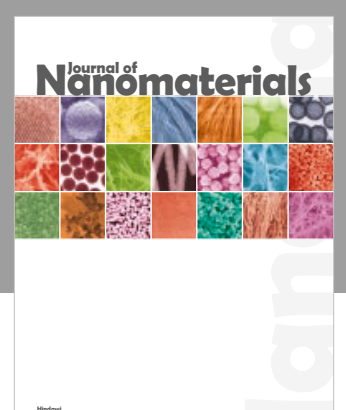

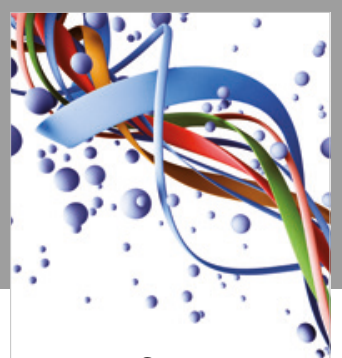

Scientifica

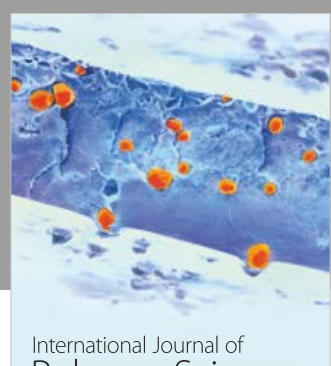

Polymer Science

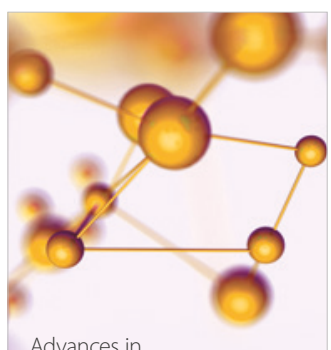

Physical Chemistry
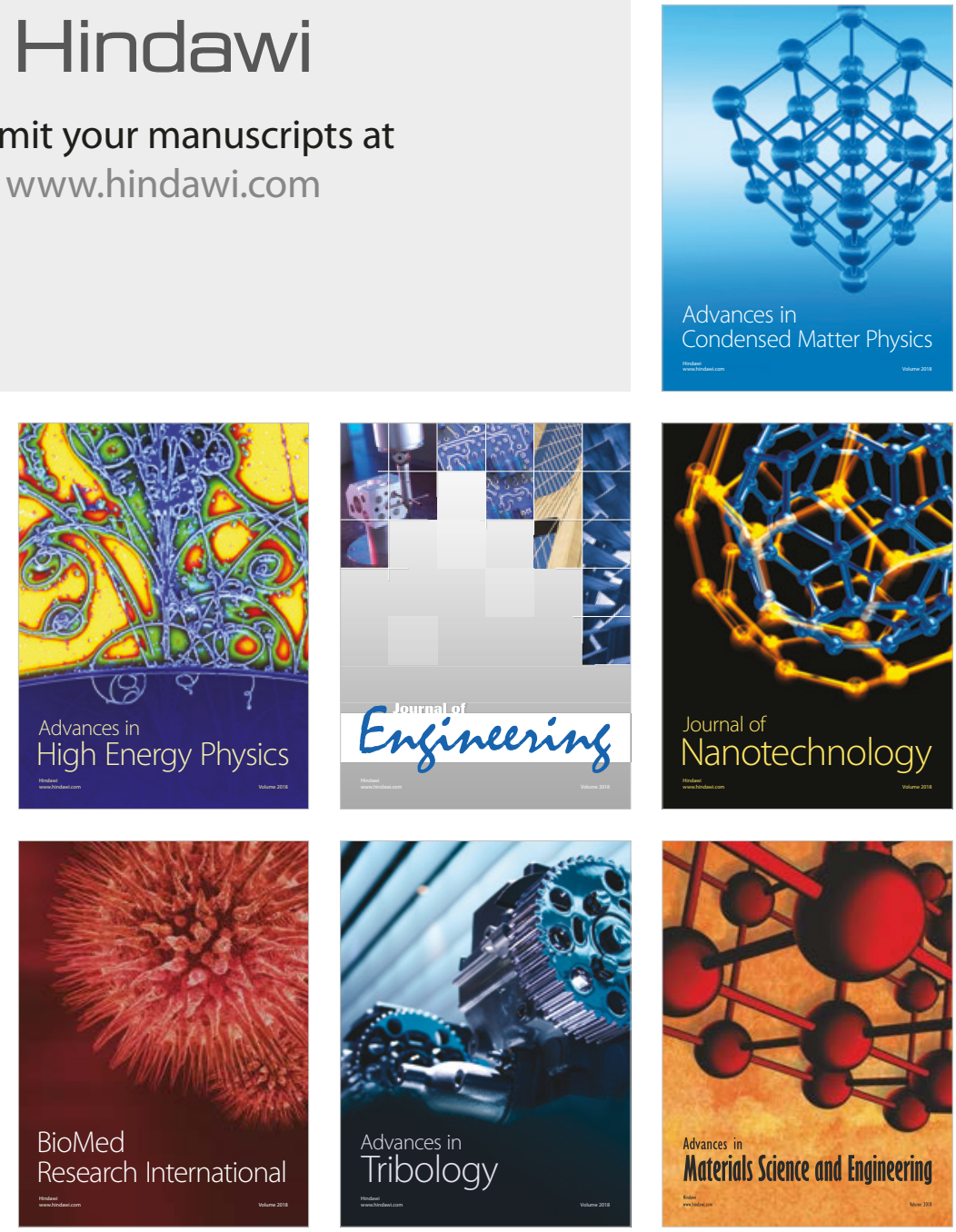